\title{
RESPONSE OF DATE PALM "Seewy cv." GROWN IN NEW RECLAIMED LAND TO ORGANIC AND INORGANIC NITROGEN SOURCES
}

\author{
Morsi, M. E. \\ Dept. of Horticulture, Fac. of Agric., Fayoum Univ., Egypt. \\ ABSTRACT \\ This investigation was carried out during 2006/2007 and 2007/2008 \\ seasons to study the effects of organic fertilization either alone or combined \\ with inorganic nitrogen fertilizer on growth, fruit set $\%$, fruit characters, yield \\ and leaf mineral content of date palm "Seewy cv." grown in sandy loamy soil. \\ Organic manure was applied at $0.0,25,50,75$ and $100 \%$ of the recommended \\ dose of nitrogen fertilization $(1300 \mathrm{~g} / \mathrm{palm} / \mathrm{year})$ combined with inorganic \\ nitrogen (ammonium nitrate $33.5 \% \mathrm{~N}$ ) at 100, 75, 50, 25 and $0.0 \%$, \\ respectively. \\ The obtained results showed that application of organic nitrogen alone \\ or combined with inorganic nitrogen significantly increased pinnae area and \\ leaf area but decreased leaf length and new leaf number per palm. Organic \\ nitrogen increased fruit set percentage in the second season. Bunch number, \\ bunch weight and yield per palm increased with increasing organic nitrogen \\ level from $50 \%$ to $100 \%$ of whole nitrogen dose/palm. Organic manure \\ increased fruit weight, fruit size, dry matter percentage, total sugars, reducing \\ sugars and total soluble solids. Total acidity and tannis were decreased by \\ application of organic nitrogen. Results also revealed that organic manure \\ increased $\mathrm{N}, \mathrm{P}, \mathrm{K}, \mathrm{Mg}, \mathrm{Ca}, \mathrm{Fe}, \mathrm{Zn}$ and $\mathrm{Mn}$ in pinnae content. \\ Finally, it is concluded that replacing $75 \%$ of nitrogen requirements for \\ Seewy date palms grown in sandy loamy soil by organic manure added once at \\ winter season was very useful in improving growth nutritional status of palms. \\ In addition, this treatments gave high yield with good fruit quality as well as \\ minimize the production cost and environment pollution which occurred by \\ chemical fertilizers.
}

Key word: organic fertilization - inorganic fertilization - growth - fruit set- yield and fruit quality - date palms - sandy soil

\section{INTRODUCTION}

Date palm (Phoenix dactylifera, L.) is an important fruit crop in the old lands as well as in the new reclaimed regions of Egypt. The number of fruitful female palms in 2007 attained 12.039 million palms produced 1.314 million tons dates. In Fayoum Governorate the number of fruitful female palms were 599254 produced 52934 tons dates, from which "Seewy" cv. were 24892 palms produced 2608.54 tons dates (according to Annals of Agricultural Economics, A.R.E, 2007).

The nutritional value of dates for human being is high. Dates are rich in many minerals such as potassium and calcium and contain a moderate amounts of copper, magnesium, phosphorus and sulpher (Nixon and Carpenter, 1978) as well as some vitamins (Yousif et. al., 1982). Also, many parts of date palm tree are useful for feeding livestock and animal or mixed with other forage fodder crops (Nour and Tag El-Din 1993).

The recent investigations demonstrated that the different sources of organic and inorganic nitrogen fertilizers caused a significant increase concerning tree growth and yield of date palms (Melouk et. al., 1999a and Melouk, 1999b). Application of organic manure minimizes the loss of nutrients by leaching (Balba, 1973) and considered as an important source of essential nutrients for plant growth (Yagodin,

Fayoum J. Agric. Res. \& Dev., Vol.23, No.1, January, 2009 
Morsi, M. E.

1984). Also, the addition of organic manure to soil not only increased the organic matter but also raised the available phosphorus and exchangeable potassium, calcium and magnesium content (Bhangoo et. al. 1988). Applying a constant amount of nitrogen $(1350 \mathrm{gm} / \mathrm{palm} / \mathrm{year})$ from different forms of organic or/and inorganic nitrogen fertilizers to Zaghloul and Samany date palm cultivars showed that, in general, Zaghloul pinnae contained higher concentrations of $\mathrm{P}, \mathrm{Fe}$ and $\mathrm{Zn}$ and lower concentrations of $\mathrm{N}$ and $\mathrm{Ca}$ as compared with those of Samany cultivar. Also, fruits of Zaghloul cultivar contained higher content of $\mathrm{N}, \mathrm{Mg}, \mathrm{Zn}$ and $\mathrm{Mn}$ and lower content of $\mathrm{P}, \mathrm{K}, \mathrm{Ca}, \mathrm{Fe}$ and $\mathrm{Cu}$ than those of Samany cultivar. Fertilizing with urea or ammonium nitrate increased pinnae and fruit content of nitrogen while some organic manure alone or combined with artificial fertilizers decreased it in pinnae and fruits. Additionally, chicken manure alone increased $\mathrm{P}$ concentration in pinnae and $\mathrm{K}$ concentration in fruits and decreased fruit content of Fe. The correlation coefficients within pinnae mineral content were positive between $\mathrm{Zn}$ in one side and $\mathrm{K}$ (in both cultivars), $\mathrm{Ca}$ and $\mathrm{P}$ in Zaghloul cultivar in the other side (Attalla et. al., 2003).

Applied organic manure treatments resulted in positive variations in the parameters of vegetative growth number of annual new leaves and the increase in palm height of the studied date palm (Seewy cv.) as well as in fruit weight, size and dry matter, total sugars, reducing sugars and yield (Aziz Nagat, 2007). Replacing 60-80\% of nitrogen requirement for Zaghloul date palm by organic manure improved growth and nutritional statues of palm as well as yield and dates quality and reduced the environmental pollution problems (El-Wasfy and El-Khawaga, 2008).

The goal of the present investigation was to study the effect of organic, inorganic nitrogen sources and the combinations between them on the vegetative growth, flower set, average mineral content of pinnae and fruit quality of "Seewy" date palms at the end of Khalal stage (harvest date).

\section{MATERIALS AND METHODS}

This investigation was under taken during 2006/2007 and 2007/2008 growing seasons on 12 years old "Seewy" date palm to study the effect of inorganic and organic nitrogen fertilizers (Ammonium nitrate $33.5 \% \mathrm{~N}$ and chicken manure). The palm trees were uniform as possible in growth and vigor, and subjected to the same cultural practices commonly adopted in the orchard and irrigated by Nile water as flood irrigation. The trees were planted at $6 \times 6 \mathrm{~m}$ apart and grown on a loamy sand soil (new reclaimed lands) at the experimental farm of the Fac. of Agric. at Demo, Fayoum, Egypt.

Other horticultural management such as irrigation, pruning, artificial pollination (pollen grains were taken from only one male palm tree) in the first and second seasons and pest control was carried out as usual. The physical and chemical characteristics of the soil and chemical analysis of organic fertilizer (chicken manure) are shown in Tables $(1 \& 2)$.

The treatments were applied in complete randomized design. Three palms were assigned for each treatment and one palm was considered as one replicate.

Phosphorus and potassium fertilizers were applied in the form of calcium super phosphate $\left(37.5 \% \mathrm{P}_{2} \mathrm{O}_{5}\right)$ and potassium sulphate $\left(48 \% \mathrm{~K}_{2} \mathrm{So}_{4}\right)$ for all treatments at the rates of 0.85 and $0.9 \mathrm{~kg} /$ tree /year, respectively.

The experiment included five treatments representing various levels of nitrogen fertilization (inorganic and organic). All palm trees were under the same recommended $\mathrm{N}$ level of $1300 \mathrm{~g} / \mathrm{palm} / \mathrm{year}$ as shown in Table (3).

The treatments were as follows.

1 - Nitrogen $100 \%$ mineral (control)

2 - Nitrogen $75 \%$ mineral $+25 \%$ organic

Fayoum J. Agric. Res. \& Dev., Vol.23, No.1, January, 2009 
RESPONSE OF DATE PALM "Seewy cv." GROWN IN

3 - Nitrogen $50 \%$ mineral $+50 \%$ organic

4- Nitrogen $25 \%$ mineral $+75 \%$ organic

5- Nitrogen $100 \%$ organic

Table (1) Physical and chemical characteristics of the soil.

\begin{tabular}{|c|c|c|c|c|c|c|c|c|c|c|}
\hline \multirow{3}{*}{ Depth } & \multicolumn{10}{|c|}{ Physical characteristics } \\
\hline & \multicolumn{4}{|c|}{ Particle size distribution } & \multirow{2}{*}{ Texture } & \multirow{2}{*}{$\begin{array}{c}\text { Bulk } \\
\text { density } \\
\text { g/cm }\end{array}$} & \multirow{2}{*}{$\begin{array}{c}\text { Organic } \\
\text { mater } \\
\%\end{array}$} & \multicolumn{3}{|c|}{$\begin{array}{c}\text { Soil moisture constant } \\
\%\end{array}$} \\
\hline & $\begin{array}{l}\text { Coarse } \\
\text { sand } \%\end{array}$ & $\begin{array}{c}\text { Fine } \\
\text { sand } \%\end{array}$ & $\begin{array}{l}\text { Silt } \\
\%\end{array}$ & $\begin{array}{c}\text { Clay } \\
\%\end{array}$ & & & & F. C & W.P & A.W \\
\hline $0-30$ & 55.14 & 28.99 & 8.21 & 7.66 & \multirow{2}{*}{$\begin{array}{c}\text { Loamy } \\
\text { Sand }\end{array}$} & 1.35 & 0.79 & 17.9 & 7.12 & 10.78 \\
\hline $30-60$ & 51.85 & 29.48 & 9.40 & 9.27 & & 1.40 & 0.70 & 20.5 & 8.80 & 11.67 \\
\hline \multicolumn{11}{|c|}{ chemical characteristics } \\
\hline & \multicolumn{4}{|c|}{ Soluble cations $(\mathrm{meq} / \mathrm{L})$} & & $\mathrm{ECe}$ & \multicolumn{4}{|c|}{ Soluble anions (meq/l) } \\
\hline & $\mathrm{Ca}^{++}$ & $\mathrm{Mg}^{++}$ & $\mathrm{Na}^{+}$ & $\mathrm{K}^{-}$ & & $(\mathrm{dS} / \mathrm{m})$ & $\mathrm{Cl}^{-}$ & $\mathrm{HcO}_{3}$ & & $\mathrm{So}_{4}^{--}$ \\
\hline $0-30$ & 16.56 & 15.42 & 11.63 & 1.2 & 7.50 & 4.49 & 7.87 & 2.70 & & 35.24 \\
\hline $30-60$ & 10.27 & 10.91 & 4.99 & 0.6 & 7.45 & 2.63 & 3.59 & 2.83 & & 20.40 \\
\hline
\end{tabular}

Table (2) chemical analysis of organic fertilizer (chicken manure)

\begin{tabular}{|c|c|c|c|c|c|c|c|c|c|c|c|}
\hline $\begin{array}{c}\text { Organic } \\
\text { fertilizers }\end{array}$ & O.M & $\mathrm{C} / \mathrm{N}$ & $\mathrm{C}$ & \multicolumn{4}{|c|}{ Macro elements } & \multicolumn{3}{|c|}{ Micro elements } \\
\cline { 5 - 12 } & ratio & $\%$ & $\mathrm{~N}$ & $\mathrm{P} \%$ & $\mathrm{~K}$ & $\mathrm{Ca}$ & $\mathrm{Mg}$ & $\begin{array}{c}\mathrm{Fe} \\
\% \\
\mathrm{ppm}\end{array}$ & $\begin{array}{c}\mathrm{Zn} \\
\mathrm{ppm}\end{array}$ & $\begin{array}{c}\mathrm{Mn} \\
\mathrm{ppm}\end{array}$ \\
\hline Chicken manure & 35.47 & 5.43 & 20.6 & 3.8 & 0.16 & 2.1 & 0.17 & 0.49 & 842.40 & 506.70 & 213.14 \\
\hline
\end{tabular}

Ammonium nitrate $(33.5 \% \mathrm{~N})$ as a source of inorganic nitrogen was applied and added at three equal doses at the $1^{\text {th }}$ March, $1^{\text {th }}$ May and $1^{\text {th }}$ July of each season.

At the last week of December, organic manure was applied (chicken manure, $3.8 \%$ $\mathrm{N}$ ), Table (2) in holes with $70 \mathrm{Cm}$. diameter and $70 \mathrm{Cm}$. depth at a distance of $70 \mathrm{Cm}$. from the palm trunk on one side in the first season and on the opposite side in the second season (Hussein and Hussein, 1983).

The present investigation was carried out to study the effect of organic and inorganic or combined nitrogen sources on the vegetative growth, flower set average mineral content of pinnae and fruit quality of "Seewy" date palms at the end of Khalal stage (harvest date).

Table (3): The amount of nitrogen in inorganic and organic sources used in this investigation

\begin{tabular}{|c|c|c|c|c|c|c|}
\hline \multirow{3}{*}{ No. } & \multirow{3}{*}{ Fertilization treatment } & \multicolumn{4}{|c|}{ Amount fertilization } & \multirow{3}{*}{$\begin{array}{c}\text { Total } \\
\text { nitrogen } \\
\text { per palm } \\
\text { (g) }\end{array}$} \\
\hline & & \multicolumn{2}{|c|}{ Mineral nitrogen } & \multicolumn{2}{|c|}{ Organic nitrogen } & \\
\hline & & $\begin{array}{l}\text { Amount/ } \\
\text { palm (kg) }\end{array}$ & \begin{tabular}{|c|} 
Net N/ \\
palm (g)
\end{tabular} & $\begin{array}{l}\text { Amount/ } \\
\text { palm (kg) }\end{array}$ & $\begin{array}{c}\text { Net N/ } \\
\text { palm (g) }\end{array}$ & \\
\hline $\mathbf{T}_{1}$ & N $100 \%$ mineral (Control) & 3.88 & 1300 & 0.0 & 0.0 & 1300 \\
\hline $\mathbf{T}_{2}$ & N $75 \% \mathrm{~m}+\mathbf{2 5 \%}$ organic & 2.91 & 975 & 8.55 & 325 & 1300 \\
\hline $\mathbf{T}_{3}$ & N 50\%+ N50\% organic & 1.94 & 650 & 17.1 & 650 & 1300 \\
\hline $\mathbf{T}_{4}$ & N $25 \%+$ N75\% organic & 0.97 & 325 & 25.65 & 975 & 1300 \\
\hline $\mathbf{T}_{5}$ & N $100 \%$ Organic & 0 & 0 & 34.21 & 1300 & 1300 \\
\hline
\end{tabular}

\section{1-Vegetative growth:}

Average number of newly growing leaves was counted at the end of each season. Five mature leaves around fruiting zone were chosen on each palm to determine leaf length $(\mathrm{m})$, number of pinnae, number of spines. Ten pinnae were taken from the

Fayoum J. Agric. Res. \& Dev., Vol.23, No.1, January, 2009 
Morsi, M. E.

middle part of each leaf to determine pinnae area according to Shabana and Antoun (1980) using the following equation:

Pinna area $\left(\mathrm{cm}^{2}\right)=$ Length $\mathrm{x}$ maximum width $\mathrm{x} 0.84$

The whole leaf area $\left(\mathrm{m}^{2}\right)$ was obtained from multiplying the pinnae area by the number of pinnae/leaf.

\section{2- Fruit set \%}

The number of set fruits per strand was counted using 10 randomly strands per spathe of each palm after thirty days from pollination.

The percentage of fruit set for each spathe was counted using the following equation as cited from Abd El- Rawy (2001).

Fruit set \% = Av. number of set fruits per strand

\section{Av. number of set fruit per strand +Av. number of flower scars}

\section{3- Fruit characters:}

The average fruit set $\%$ of each palm was calculated.

Samples of 90 fruits per palm were collected randomly at harvest to determine the physical properties of the fruits. Fruit weight $(\mathrm{gm})$, fruit size $\left(\mathrm{cm}^{3}.\right)$, dry matter $(\%)$ and flesh percentage were determined and the average of each property was calculated.

\section{4- Chemical characteristics of fruits:}

Dry matter percentage, total sugars, reducing sugars, (g/100g dry wt.), total soluble solids (T.S.S.), and acidity content of the juice were determined according to the methods outlined in the (A.O.A.C. (1990).

\section{5- Tannins content:}

The official method described by Winton \& Winton (1958) was used. Indigo carmine solution was the indicator and titration was carried out using $0.1 \mathrm{~N}$ of potassium permanganate. Tannins content was calculated as gm. tannins per $100 \mathrm{gm}$. fresh weight according to the following equation: $1 \mathrm{ml}$. oxalic acid $(0.1 \mathrm{~N})=0.00416$ gm. tannins.

6- Yield

All bunches of each palm in both seasons were harvested at full colour stage (khalal). The harvested bunches of each palm were weighed to determine the yield (kg) / palm.

\section{7- Leaf mineral content:}

To determine leaf mineral content (N, P, K, Ca, Mg, Fe, Zn and Mn), twenty five pinnae (as a sample) from each replicate were collected at mid-November of both seasons as described by (Rizk, 1987). Total nitrogen was determined colorimetrically according to (Evanhuis, 1976), whereas potassium was determined by Flamephotometer. Phosphorus, calcium, magnesium, iron, zinc and manganese were determined by Perklin Elemer Atomic Absorption Sepectrophotometer No. 305B. The concentrations of $\mathrm{N}, \mathrm{P}, \mathrm{K}, \mathrm{Ca}$ and $\mathrm{Mg}$ were expressed as percent, while $\mathrm{Fe}, \mathrm{Zn}$ and $\mathrm{Mn}$ were expressed as parts per million (on dry weight basis).

The proper statistical analysis randomize complete block design was carried out according to the methods outlined by Snedecor and Cochran (1980) using L.S.D. test for distinguishing treatment means.

Fayoum J. Agric. Res. \& Dev., Vol.23, No.1, January, 2009 


\section{RESULTS AND DISCUSSION}

\section{1- Effect of fertilization treatments on vegetative growth}

The effects of organic and inorganic fertilization on some vegetative growth characters of "Seewy" date palms during 2006/2007 and 2007/2008 seasons are shown in Table (4). Data indicated that treatments of $25 \%$ mineral nitrogen $+75 \%$ organic nitrogen $\left(\mathrm{T}_{4}\right)$ and $100 \%$ organic nitrogen $\left(\mathrm{T}_{5}\right)$ significantly decreased new leaf number per palm in the second season. Also, significant decreases of leaf length and pinnae number were observed when applied treatments of combined inorganic and organic nitrogen $\left(T_{2}, T_{3}, T_{4}\right.$ and $\left.T_{5}\right)$ in the two successive seasons. Contrarily, significant increases in pinnae area and leaf area were obtained by treatments $\left(T_{2}, T_{3}, T_{4}\right.$ and $\left.T_{5}\right)$ compared with the control (100\% inorganic nitrogen) in the two seasons. Such findings concerning using organic-N fertilizer may be mainly attributed to its positive action on increasing the activity of microflora, water holding capacity, soil acidity, soil humus content and the availability of most macro and micro nutrients. Moreover, they can provide most nutrients to palms along the whole growth season. Such improving and stimulation lead to enhancing the biosynthesis of organic foods and cell division (Nijjar, 1985).

These results are in agreement with those obtained by Ghafoor and Gopan (1988), Abdel-Hamed and Ragab (2004), Mohamed and Gobara (2004), Mansour et al. (2004), Diab (2006). Aziz, Nagat (2007) who found that applying organic manure resulted in positive variations in the parameters of vegetative growth of "Seewy" date palm. Moreover, El-Wasfy and El-Khawaga (2008) reported positive vegetative growth response of Zaghloul date palm cultivar to the annual application of organic fertilizers.

Table (4): Effect of inorganic and organic fertilization treatments on the vegetative growth of date palm (Seewy cv.) in 2007 and 2008 seasons.

\begin{tabular}{|c|c|c|c|c|c|c|c|c|c|c|c|}
\hline \multirow[t]{2}{*}{ No. } & \multirow[t]{2}{*}{ Treatments } & \multicolumn{2}{|c|}{$\begin{array}{c}\text { No. } \\
\text { Leaf /palm } \\
\text { year }\end{array}$} & \multicolumn{2}{|c|}{$\begin{array}{l}\text { Leaf length } \\
\quad(\mathrm{cm} .)\end{array}$} & \multicolumn{2}{|c|}{$\begin{array}{c}\text { No. } \\
\text { Pinnae /leaf }\end{array}$} & \multicolumn{2}{|c|}{$\begin{array}{c}\text { Pinnae area } \\
\left(\mathrm{cm}^{2}\right)^{2}\end{array}$} & \multicolumn{2}{|c|}{$\begin{array}{c}\text { Leaf } \\
\text { Area }\left(\mathrm{m}^{2}{ }^{2}\right)\end{array}$} \\
\hline & & 2007 & 2008 & 2007 & 2008 & 2007 & 2008 & 2008 & 2008 & 2007 & 2008 \\
\hline$\left(\mathrm{T}_{1}\right)$ & $\begin{array}{r}100 \% \min \\
\text { (Co }\end{array}$ & 23.74 & 24.84 & 516.67 & 534.43 & 237.15 & 241.22 & 138.62 & 151.2 & 3.27 & 3.51 \\
\hline$\left(\mathrm{T}_{2}\right)$ & $\begin{array}{l}75 \% \min \\
25 \% \text { org }\end{array}$ & 22.63 & 23.83 & 493.066 & 506.74 & 225.55 & 233.69 & 156.73 & 175.99 & 3.71 & 3.97 \\
\hline$\left(\mathrm{T}_{3}\right)$ & $\begin{array}{l}50 \% \text { miner } \\
50 \% \text { orgar }\end{array}$ & 22.05 & 24.30 & 480.156 & 485.95 & 232.40 & 231.47 & 167.49 & 184.39 & 3.82 & 4.25 \\
\hline$\left(\mathrm{T}_{4}\right)$ & $\begin{array}{r}25 \% \text { mineral ni } \\
75 \% \text { organic n }\end{array}$ & 22.41 & 22.84 & 486.92 & 497.97 & 227.40 & 240.45 & 178.65 & 181.5 & 3.77 & 4.29 \\
\hline$\left(\mathrm{T}_{5}\right)$ & $100 \%$ organic nitrogen & 22.24 & 21.13 & 480.336 & 487.79 & 221.51 & 233.32 & 181.35 & 179.35 & 4.12 & 3.95 \\
\hline & L.S.D 0.05 & N.S & 1.30 & 4.05 & 8.37 & 2.76 & 1.94 & 1.63 & 1.49 & 0.05 & 0.21 \\
\hline
\end{tabular}

\section{2- Effect of fertilization treatments on fruit set. \%, bunch traits and yield:}

Data in Table (5) showed that fruit set \% significantly increased by fertilization treatment of $50 \%$ mineral nitrogen $+50 \%$ organic nitrogen $\left(\mathrm{T}_{3}\right), 25 \%$ mineral nitrogen $+75 \%$ organic nitrogen $\left(\mathrm{T}_{4}\right)$ and $100 \%$ organic nitrogen $\left(\mathrm{T}_{5}\right)$ in the second season. Meanwhile, results of the first season showed no significant differences between the effect of all treatments in this respect. $\left(\mathrm{T}_{5}\right)$ and $\left(\mathrm{T}_{4}\right)$ recorded high percent of fruit set (92.94\% and 93.32) in the second season.

A significant promotion on bunch number, bunch weight and yield per palm occurred with increasing organic nitrogen level from $50 \%$ to $100 \%\left(\mathrm{~T}_{3}\right.$ to $\left.\mathrm{T}_{5}\right)$

Fayoum J. Agric. Res. \& Dev., Vol.23, No.1, January, 2009 
Morsi, M. E.

compared to nitrogen application of $100 \%$ inorganic (T1) and $75 \%$ inorganic $+25 \%$ organic (T2) in the two successive seasons 2007 and 2008 respectively (Table 5).

Fertilization of "Seewy" date palm by $25 \%$ mineral nitrogen $+75 \%$ organic nitrogen (T4) recorded the best results for bunch number (13.30 \& 13.65), bunch weight $(9.29 \mathrm{~kg} \& 9.35 \mathrm{~kg})$ and yield $(122.32 \mathrm{~kg} \& 127.65 \mathrm{~kg})$ per palm.

The increase in yield per palm could be attributed to the effect of organic manure on increasing the bunch number and bunch weight during the two studied seasons. In addition, the improving effect of organic manure on bunch number per palm and bunch weight could be also attributed to its vital role in improving vegetative growth of palm and nutritional status which encourage the cell division and the development of meristematic tissues and consequently improving the number of inflorescences borne (Miller et al., 1990).

These results are in harmony with those obtained by Hussein et al. (1992), Shahein et al. (2003), Attalla et al., (2003) on Zaghloul and Samany cultivars. ElAssar (2005) who found that yield of Zaghloul and Samany date palms seemed to be higher as a result of fertilizing with organic-N source either alone or combined with the artificial nitrogen sources. El-Wasfy and El-Khawaga (2008) reported that increasing the organic nitrogen level substantially from $12.5 \%$ to $75 \%$ of the recommended nitrogen rate was followed by a gradually improving yield and fruit quality of Zaghloul date palm growing in sandy soil.

Table (5): Effect of inorganic and organic fertilization treatments on fruit set\% and yield components of date palm (Seewy cv.) in 2007 and 2008 seasons.

\begin{tabular}{|c|c|c|c|c|c|c|c|c|c|}
\hline \multirow[t]{2}{*}{ No. } & \multirow[t]{2}{*}{ Treatments } & \multicolumn{2}{|c|}{$\begin{array}{l}\text { Fruit } \\
\text { set. } \%\end{array}$} & \multicolumn{2}{|c|}{$\begin{array}{c}\text { Bunch } \\
\text { No./Palm }\end{array}$} & \multicolumn{2}{|c|}{$\begin{array}{c}\text { Bunch weight } \\
(\mathrm{Kg})\end{array}$} & \multicolumn{2}{|c|}{$\begin{array}{c}\text { Yield/Palm } \\
(\mathrm{Kg})\end{array}$} \\
\hline & & 2007 & 2008 & 2007 & 2008 & 2007 & 2008 & 2007 & 2008 \\
\hline$\left(\mathrm{T}_{1}\right)$ & $100 \%$ min & 90.45 & 88.10 & 11.40 & 11.57 & 7.75 & 7.95 & 88.35 & 92.07 \\
\hline$\left(\mathrm{T}_{2}\right)$ & $\begin{array}{l}75 \% \text { mine } \\
25 \% \text { org }\end{array}$ & 89.13 & 87.42 & 11.24 & 11.79 & 8.09 & 8.22 & 99.12 & 104.11 \\
\hline$\left(\mathrm{T}_{3}\right)$ & $\begin{array}{r}50 \% \mathrm{mi} \\
50 \% \text { or }\end{array}$ & 88.35 & 91.00 & 12.85 & 12.99 & 8.72 & 9.1 & 112.11 & 118.25 \\
\hline$\left(\mathrm{T}_{4}\right)$ & $\begin{array}{r}25 \% \text { miner } \\
75 \% \text { orgar }\end{array}$ & 89.47 & 92.94 & 13.3 & 13.65 & 9.29 & 9.35 & 122.32 & 127.65 \\
\hline$\left(T_{5}\right)$ & $100 \% 0$ & & 93. & 12.7 & 12.78 & 9.2 & 9.20 & 120.24 & 125.11 \\
\hline & L.S.D 0.05 & N.S & 2.28 & 0.39 & 0.44 & 0.85 & 0.98 & 12.11 & 13.00 \\
\hline
\end{tabular}

\section{3- Effect of fertilization treatments on some fruit physical characteristics}

Data in Table (6) indicated that supplying "Seewy" date palms with 25\%, 50\%, $75 \%$ and $100 \%$ organic nitrogen gave significant increase in fruit weight in 2006/2207 and 2007/2008 seasons compared with 100\% inorganic nitrogen application (control).

All fertilization treatments had no significant effect on fruit size on the first season (2007), however, in the second season (2008) it increased when a mixture organic and inorganic nitrogen were used.

Data in Table (6) also shows that using $25 \%$ inorganic-N-plus $75 \%$ organic-N (T4) gave the best fruit dry matter.

Contrary, all fertilization treatments had no significant effect on flesh percentage in two successive seasons.

These results are in accordance with those obtained by Shahein et al. (2003), Abdel-Hamed and Ragab (2004), Mohamed and Gobara (2004), Mansour et al. (2004), El-Assar (2005), Diab (2006) and El-Wasfy and El-Khawaga (2008) who

Fayoum J. Agric. Res. \& Dev., Vol.23, No.1, January, 2009 
RESPONSE OF DATE PALM "Seewy cv." GROWN IN.

166

reported that increasing the organic nitrogen level substantially from 60 to $100 \%$ of the recommended nitrogen rate was followed by a gradually improving of fruit quality

\section{4- Effect of fertilization treatments on some chemical fruit qualities:}

It can be concluded from data in Table (7) that using organic nitrogen either alone or in combination with an inorganic nitrogen source was significantly effective in improving fruit quality of Seewy dates in terms of increasing total sugars, reducing sugars and total soluble solids (TSS), but on the other hand, it decreased the total acidity \% and tannis \% compared to using inorganic nitrogen alone.

These findings may be related to the effect of organic-N on activating the synthesis of total carbohydrates and proteins which enhances cell division and enlargement leading to increase date weight and size as well as, hasten its maturation.

Such obtained results are in line with those of Shahein et al. (2003), Abdel-Hamed and Ragab (2004), Mohamed and Gobara (2004), Mansourr et al. 2004), El-Assar (2005), Diab (2006) and Aziz, Nagat (2007) on Seewy date palm, El-Wasfy and ElKhawaga (2008) on "Zaghloul" date palm, who reported that increasing organic nitrogen level substantially from $60 \%$ to $100 \%$ of recommended nitrogen rate was followed by a gradual improving of fruit quality.

Table (6): Effect of inorganic and organic fertilization treatments on some fruit physical characteristics of date palm (Seewy cv.) in 2007 and 2008 seasons.

\begin{tabular}{|c|c|c|c|c|c|c|c|c|c|}
\hline \multirow{2}{*}{ No. } & \multirow{2}{*}{ Treatments } & \multicolumn{2}{|c|}{ Fruit weight (g) } & \multicolumn{2}{|c|}{ Fruit size $\left(\mathrm{cm}^{3}\right)$} & \multicolumn{2}{|c|}{ Dry matter \% } & \multicolumn{2}{|c|}{ Flesh (\%) } \\
\hline & & 2007 & 2008 & 2007 & 2008 & 2007 & 2008 & 2007 & 2008 \\
\hline$\left(\mathbf{T}_{1}\right)$ & $\begin{array}{l}100 \% \text { mineral nitrogen } \\
(\text { Control })\end{array}$ & 13.29 & 14.88 & 11.14 & 11.62 & 19.95 & 21.60 & 90.01 & 90.08 \\
\hline$\left(\mathbf{T}_{2}\right)$ & $\begin{array}{l}75 \% \text { mineral nitrogen }+ \\
25 \% \text { organic nitrogen }\end{array}$ & 15.70 & 15.55 & 11.52 & 12.82 & 23.86 & 24.86 & 90.15 & 90.64 \\
\hline$\left(\mathbf{T}_{3}\right)$ & $\begin{array}{c}50 \% \text { mineral nitrogen }+ \\
50 \% \text { organic nitrogen }\end{array}$ & 16.54 & 16.95 & 11.65 & 13.04 & 24.56 & 25.95 & 90.83 & 90.89 \\
\hline$\left(\mathbf{T}_{4}\right)$ & $\begin{array}{c}25 \% \text { mineral nitrogen }+ \\
75 \% \text { organic nitrogen }\end{array}$ & 17.85 & 18.34 & 11.95 & 13.69 & 25.54 & 26.12 & 90.88 & 90.91 \\
\hline$\left(\mathbf{T}_{5}\right)$ & $100 \%$ organic nitrogen & 16.55 & 17.64 & 12.42 & 14.27 & 25.33 & 26.81 & 91.02 & 91.99 \\
\hline & L.S.D 0.05 & 1.01 & 0.55 & n.s. & 1.10 & 2.46 & 2.11 & n.s. & n.s. \\
\hline
\end{tabular}

Table (7): Effect of different fertilization treatments on some fruit chemical constituents of date palm (Seewy cv.) in 2007 and 2008 seasons.

\begin{tabular}{|c|c|c|c|c|c|c|c|c|c|c|c|}
\hline \multirow[t]{2}{*}{ No. } & \multirow[t]{2}{*}{ Treatments } & \multicolumn{2}{|c|}{$\begin{array}{c}\text { Total sugars } \\
\text { \% (g/100g) } \\
\text { D.W }\end{array}$} & \multicolumn{2}{|c|}{$\begin{array}{c}\text { Reducing } \\
\text { sugars \% } \\
\text { (g/100 g) D.W }\end{array}$} & \multicolumn{2}{|c|}{$\begin{array}{c}\text { Acidity } \\
\%\end{array}$} & \multicolumn{2}{|c|}{$\begin{array}{c}\text { TSS } \\
\%\end{array}$} & \multicolumn{2}{|c|}{$\begin{array}{l}\text { Tannins } \\
(\%) \text { F.W }\end{array}$} \\
\hline & & 2007 & 2008 & 2007 & 2008 & 2007 & 2007 & 2008 & 2008 & 2007 & 2008 \\
\hline$\left(\mathbf{T}_{1}\right)$ & $\begin{array}{c}100 \% \text { mineral } \\
\text { nitrogen (Control) }\end{array}$ & 35.24 & 37.11 & 24.58 & 24.51 & 0.041 & 0.046 & 41.5 & 47.7 & 0.5 & 0.6 \\
\hline$\left(\mathbf{T}_{2}\right)$ & $\begin{array}{l}75 \% \text { mineral nitrogen + } \\
25 \% \text { organic nitrogen }\end{array}$ & 37.58 & 38.81 & 25.12 & 25.05 & 0.032 & 0.039 & 45.3 & 48.8 & 0.4 & 0.4 \\
\hline$\left(\mathbf{T}_{3}\right)$ & $\begin{array}{l}50 \% \text { mineral nitrogen + } \\
50 \% \text { organic nitrogen }\end{array}$ & 38.99 & 39.01 & 26.65 & 26.77 & 0.031 & 0.035 & 47 & 48.1 & 0.3 & 0.3 \\
\hline$\left(\mathbf{T}_{4}\right)$ & $\begin{array}{l}25 \% \text { mineral nitrogen }+ \\
75 \% \text { organic nitrogen }\end{array}$ & 40.84 & 40.22 & 26.75 & 27.01 & 0.028 & 0.029 & 48.5 & 49.6 & 0.2 & 0.2 \\
\hline$\left(\mathbf{T}_{5}\right)$ & $100 \%$ organic nitrogen & 40.89 & 40.29 & 26.98 & 27.54 & 0.026 & 0.027 & 49 & 49.9 & 0.2 & 0.2 \\
\hline & \begin{tabular}{|l|} 
L.S.D 0.05 \\
\end{tabular} & 2.46 & 2.11 & 1.56 & 1.60 & 0.002 & 0.002 & 0.64 & 0.81 & 0.1 & 0.1 \\
\hline
\end{tabular}

Fayoum J. Agric. Res. \& Dev., Vol.23, No.1, January, 2009 


\section{5- Effect of fertilization treatments on pinnae macro and micro nutrients:}

As for the effect of different organic and inorganic fertilization treatments on pinnae mineral content, results in Tables (8 and 9) indicated that using organic manure alone or combined with artificial fertilizer (ammonium nitrate) in 2007 and 2008 seasons, respectively had a significant effect on pinnae nitrogen, phosphorus, potassium and magnesium content than that of the most fertilized trees with ammonium nitrate alone.

These results are in agreement with those of Abdel-Hamed and Ragab (2004) on Seewy date palm, El-Wasfy and El-Khawaga (2008) on Zaghloul date palm cv. who studied the effect of different fertilization treatments on pinna nitrogen, phosphorus, potassium and magnesium content. They found that these minerals were significantly higher in case of chicken manure fertlization alone or combined with ammonium nitrate in both seasons.

Regarding the effect of fertilization treatments on pinnae calcium content, it was detected that using chicken manure alone or combined with $25 \%$ mineral nitrogen in the second season (2007/2008) had a significant higher pinnae content compared with the control (100\% mineral nitrogen). However, in the first season 2006/2007, there were no significant differences in this concern.

Table (8): Effect of different fertilization treatments on pinnae content of macronutrient percentage (on dry weight basis) of Seewy date palms in 2007 and 2008 seasons.

\begin{tabular}{|c|c|c|c|c|c|c|c|c|c|c|c|}
\hline \multirow{2}{*}{$\begin{array}{c}\text { No } \\
\text {. }\end{array}$} & \multirow{2}{*}{ Treatments } & \multicolumn{2}{|c|}{$\mathbf{N \%}$} & \multicolumn{2}{|c|}{$\mathbf{P \%}$} & \multicolumn{2}{|c|}{$\mathbf{K} \%$} & \multicolumn{2}{|c|}{$\mathrm{Ca} \%$} & \multicolumn{2}{|c|}{$\mathrm{Mg \%}$} \\
\hline & & 2007 & 2008 & 2007 & 2008 & 2007 & 2008 & 2007 & 2008 & 2007 & 2008 \\
\hline$\left(\mathbf{T}_{1}\right)$ & $\begin{array}{c}100 \% \text { mineral nitrogen } \\
\text { (Control) }\end{array}$ & 1.60 & 1.42 & 0.137 & 0.141 & 0.866 & 0.821 & 1.10 & 1.22 & 0.546 & 0.542 \\
\hline$\left(\mathbf{T}_{2}\right)$ & $\begin{array}{l}75 \% \text { mineral nitrogen+ } \\
25 \% \text { organic nitrogen }\end{array}$ & 1.71 & 1.59 & 0.141 & 0.148 & 0.956 & 1.08 & 1.11 & 1.25 & 0.559 & 0.562 \\
\hline$\left(\mathbf{T}_{3}\right)$ & $\begin{array}{l}\mathbf{5 0 \%} \text { mineral nitrogen } \\
+\mathbf{5 0 \%} \text { organic nitrogen }\end{array}$ & 1.69 & 1.65 & 0.142 & 0.150 & 1.11 & 1.10 & 1.12 & 1.29 & 0.560 & 0.565 \\
\hline$\left(\mathbf{T}_{4}\right)$ & $\begin{array}{c}25 \% \text { mineral nitrogen }+ \\
\mathbf{7 5 \%} \text { organic nitrogen }\end{array}$ & 1.67 & 1.71 & 0.145 & 0.154 & 1.18 & 1.16 & 1.12 & 1.31 & 0.563 & 0.566 \\
\hline$\left(\mathbf{T}_{5}\right)$ & $100 \%$ organic nitrogen & 1.65 & 1.66 & 0.160 & 0.162 & 1.22 & 1.19 & 1.12 & 1.35 & 0.563 & 0.541 \\
\hline & L.S.D 0.05 & 0.03 & 0.04 & 0.003 & 0.004 & 0.006 & 0.009 & N.S & 0.02 & 0.004 & 0.005 \\
\hline
\end{tabular}

As for pinnae iron content, there was a significant increase as a result of applying chicken manure plus ammonium nitrate (T3, T4 and T5 in 2006/2007 and 2007/2008 seasons (Table 9). The obtained results are in agreement with those of (Ismail, 1999) on Hayany date palm cultivar, Abd El-Naby et al., (2000) on Maghrabi banana. They found that adding a organic combination of organic and inorganic fertilizers produced fruits with higher content of iron. Concerning zinc, Attalla et al. (2003) on Zaghloul and Samany cultivars

Concluded that, pinnae content of zinc was significantly higher in case of using chicken manure alone or combined with ammonium nitrate treatments in 2006/2007 and 2007/2008, respectively, than that in case of inorganic nitrogen fertilization alone (ammonium nitrate treatment).

The palm trees fertilized with chicken manure alone or plus ammonium nitrate had a significant higher pinnae manganese content in 2008 as compared with ammonium nitrate alone. These findings are partially in harmony with those of Sourour $\boldsymbol{e t}$ al. (1998), Abdel-Nasser and Harhash (2001) and Attalla et al., (2003). They found

Fayoum J. Agric. Res. \& Dev., Vol.23, No.1, January, 2009 
RESPONSE OF DATE PALM "Seewy cv." GROWN IN.

that the highest values of pinnae zinc and manganese content always come from adding organic plus inorganic nitrogen sources.

Table (9): Effect of different fertilization treatments on pinnae content of micronutrient (ppm) (on dry weight basis) of date palm (Seewy cv.) in 2007 and 2008 seasons.

\begin{tabular}{|c|c|c|c|c|c|c|c|}
\hline \multirow{2}{*}{ No. } & \multirow{2}{*}{ Treatments } & \multicolumn{2}{|c|}{ Fe (ppm) } & \multicolumn{2}{|c|}{ Zn (ppm) } & \multicolumn{2}{|c|}{ Mn (ppm) } \\
\hline & & 2007 & 2008 & 2007 & 2008 & 2007 & 2008 \\
\hline$\left(\mathbf{T}_{1}\right)$ & $100 \%$ mineral nitrogen (Control) & 95 & 97 & 66.66 & 74.11 & 65 & 66 \\
\hline$\left(\mathbf{T}_{2}\right)$ & $\begin{array}{l}75 \% \text { mineral nitrogen }+ \\
25 \% \text { organic nitrogen }\end{array}$ & 96 & 98 & 67.89 & 75.55 & 64 & 68 \\
\hline$\left(\mathbf{T}_{3}\right)$ & $\begin{array}{l}50 \% \text { mineral nitrogen }+ \\
50 \% \text { organic nitrogen }\end{array}$ & 98 & 100 & 68.16 & 76.88 & 64 & 68 \\
\hline$\left(\mathbf{T}_{4}\right)$ & $\begin{array}{l}25 \% \text { mineral nitrogen }+ \\
75 \% \text { organic nitrogen }\end{array}$ & 99 & 103 & 69.24 & 76.98 & 65 & 69 \\
\hline$\left(\mathbf{T}_{5}\right)$ & $100 \%$ organic nitrogen & 101 & 108 & 73.43 & 78.65 & 65 & 68 \\
\hline & L.S.D 0.05 & 2.64 & 2.15 & 1.16 & 1.12 & 1.88 & 1.88 \\
\hline
\end{tabular}

Finally, it is concluded that replacing $75 \%$ of nitrogen requirements for Seewy date palms growing in sandy loamy soil by organic manure in form of chicken manure added once at the winter was very useful in improving growth nutritional status of palms. In addition, it gave high yield with good fruit quality as well as minimizing the production costs and environment pollution which could be occurred by chemical fertilizers.

\section{REFERANCES}

Abd El-Naby, S.K.M. and A.M. Gomaa. (2000). Growth, nutritional status, yield and fruit quality of Maghrabi banana as affected by some organic manures and biofertilizer. Minufiya J. Agric.Res. 25 (4): 1113-1129.

Abdel-Hameed, M. A. and M. A. Ragab (2004). Response of Seewy date palm to application of some organic fertilizers. Abstract of the Second Inter. Conf. on Date palm. Fac. Agric., El-Arish, Suze Canal Univ., Egypt.

Abdel-Nasser, G. and M.M. Harhash (2001). Studies on some plant growing Media for olive cultivation in sandy soils under Siwa Oasis Conditions. J. of the Advances in Agric. Res., Univ. of Alex., Fac. of Agric Saba-Bacha. 6 (2): 487510.

Abd El-Rawy, H. (2001). Effect of different source of pollen on yield and fruit quality in some date palm cultivars. M.Sc. Thesis, Fac. Agric. Assiut Univ.

Annals of Agricultural Economics, A.R.E.( 2007). Ministry of Agriculture and Land Reclamation, Economic Affairs Sector. Agricultural Statistics Table (75). Arab Republic of Egypt.

Association of Official Agricultural Chemists.(1990). Official Methods of Analysis (A.O.A.C.) $15^{\text {th }}$ ed. Published by A.O.A.C. Washington, D.C. (U.S.A.).

Attalla, A.M.; A.H. Shahein ; H.A. Kassem and Hoda S.H.Aly (2003). Effect of applying different organic and inorganic nitrogen sources to Zaghloul and Samany date palm cultivars on: I. Leaf and fruit mineral content. International Conference on Date Palm, 16 -19 September Saudi Arabia.

Aziz, Nagat G.M. (2007). Impact of water regime and organic manure application on some characteristics of soil and date palms grown thereon. Egypt. J. of Appl. Sci., 22 (3): 319-330.

Balba, A. (1973 ). Organic and inorganic fertilization of sandy soils. FAO soils Bull., No. 21 Sandy soils 23-46, Rome.

Fayoum J. Agric. Res. \& Dev., Vol.23, No.1, January, 2009 
Morsi, M. E.

Bhangoo, M.S.; K.S. Day; V.R. Sudanagunta and V.E. Petrucci (1988). Application of poultry manure influences Thompson seedless grape. Production and soil properties. Hort. Science 23 (6), 1010-1012.

Diab, Y.M. (2006). Effect of some culture practices on yield and fruit quality of Phoenix dactylifera L. cv. Seewy under New Valley conditions. M. Sc. Thesis Fac. Agric. Assuit Univ., Egypt.

El-Assar, A.M. (2005). Response of "Zaghloul" date yield and fruit characteristics to various organic and inorganic fertilization types as well as fruit thinning models in rich carbonate soil. J. Agric Sci. Mansoura Univ., 30(5): 2795-2814.

El-Wasfy, M.M. and Abdel-Aziz S. El-Khawaga (2008). Effect of organic fertilization on growth, yield and fruit quality of Zaghloul date palm grown in sandy soil. Assuit J. of Agric. Sci., 39 (1): 121-133

Evanhuis, B. (1976). Nitrogen determination Dept. Agric. Res. Royal Tropical Inst., Amsterdam.

Ghafoor, A. and A.D. Gopang (1988). Date palm culture in Pakistan. Progressive Farming, 8(1): 8-13.

Hussein, F. and M.A. Hussein (1983). Effect of nitrogen fertilization on growth, Yield and fruit quality of Sakkoti dates grown at Aswan. In Proceedings of the First Symposium on the Date Palm in Saudi Arabia Al-Hasa, Saudi Arabia (1): 182-189.

Hussein, M.A., S.Z. El-Agamy, K.A. Amen and S. Galal (1992). Effect of certain fertilization and thinning applications on the yield and fruit quality of Zaghloul date palm. Assuit J. Agric. Sci., 23(2): 349-360.

Ismail, S.A.M. (1999). Effect of fertilization on yield of Hayany date at El-Arish. M.sc. Thesis. Fac. of Enviro. Aricultural Sci., El-Arish, Suez Canal Univ., Egypt.

Mansour, A.E. M.; F.F. Ahmed and Y.M. Ahmed (2004). Effect of bio and organic sources of $\mathrm{N}$ as a partial substitute for mineral fertilization of fruiting of Seewy date palms. The Second Inter. Conf. on Date palm. Fac. Agric., El-Arish, Suze Canal Univ., Egypt

Melouk, A.M., M.A. Basal and U.K. El-Abbasy (1999a). Effect of nitrogen fertilization on growth and yield of Zaghloul date palm. I. Vegetative growth and leaf mineral content. The International Conferemce on Date Palm. Assiut, Egypt. : 237-253.

Melouk, A.M.; M.A. Basal and U.K. El-Abbasy (1999b). Effect of nitrogen fertilization on growth and yield of Zaghloul date palm II. Yield and fruit quality. The International Conference on Date Palm. Assiut, Egypt.: 255-269.

Miller, E.W.; R.L. Donahua and J.U. Miller (1990). Soil an introduction to soils and plant growth. Brentice Hall International Inc. Engle Word Cliffs, New Jersy, pp. 210-220.

Mohamed, G.A. and A.A. Gobara (2004). Response of Seewy date palms grown under New Valley conditions to organic, bio and mineral fertilization. Minia J. of Agric Res. \& Develop. 24 (3): 397-414.

Nijjar, G.S. (1985). Nutrition of fruit trees. Mrs Usha Raj Kumar, Kalyani, New Delhi, pp.10-20.

Nixon, R.W. and J.B. Carpenter (1978). Growing dates in the United States. Dept. of Agric., Washington, D.C.

Nour, A.M. and A.E. Tag El-Din. (1993). Evalution of palm tree leaves and date stones in complete diets fed to growing sheep. Abstract of the Third Symposium on Date Palm in Saudi Arabia, Jan. 17-20, P. 171.)

Fayoum J. Agric. Res. \& Dev., Vol.23, No.1, January, 2009 
RESPONSE OF DATE PALM "Seewy cv." GROWN IN.

Rizk, S.A.Y. (1987). Studied on the effect of fertilization on date palm production. Ph.D. Thesis. Fac. Agric., Ain Shams Univ., Egypt.

Sourour, M.M.; M.B. El-Sabrout and I.A. Mousa (1998). Effect of some sea weeds and mineral nitrogen fertilization treatments on growth, yield, fruit quality and nutritional status of "Samany and Hayany" date palms grown in North-Sinai .Egypt. J. Appl. Sci.; 13(12): 247- 261.

Shabana H.R. and N.S. Antoun (1980). The determination of leaf area in date palm. Beitroya zur Tropischen Land Wirtschaft and Veterinar Medizin. 18 (4): $345-$ 349. (c.f. Hort. Abst. 51: 9012)

Shahein, A.H., A.M. Attalla, H.A. Kassem and H.S.H. Aly (2003). Effect of applying different organic and inorganic nitrogen sources to Zaghloul and Samany date palm cultivars on: II- Yield, fruit quality and fruit content of some pollutants. Proceeding on Date palm. King Saud University. Kingdom of Saudi Arabua. P. 195-205.

Snedecor, G.W. and W.G., Cochran (1980). Statistical Methods. Oxford and J.B. publishing Co., $6^{\text {th }}$ edition.

Yagodin, B.A. (1984). Agricultural Chemistry, English translation, Mir Publisher, Moscow.

Winton, A.L. and K.B. Winton. (1958). The Analysis of Food. John Wiley and Sons, Inc., London.

Yousif, A.K.; N..D. Benjamin; A. Kado; A.S. Mehi-Alddin and S.M. Ali. (1982). Chemical composition of four Iraqi date cultivars. The Date Palm Journal. Vol. 1 (2): 285-294.

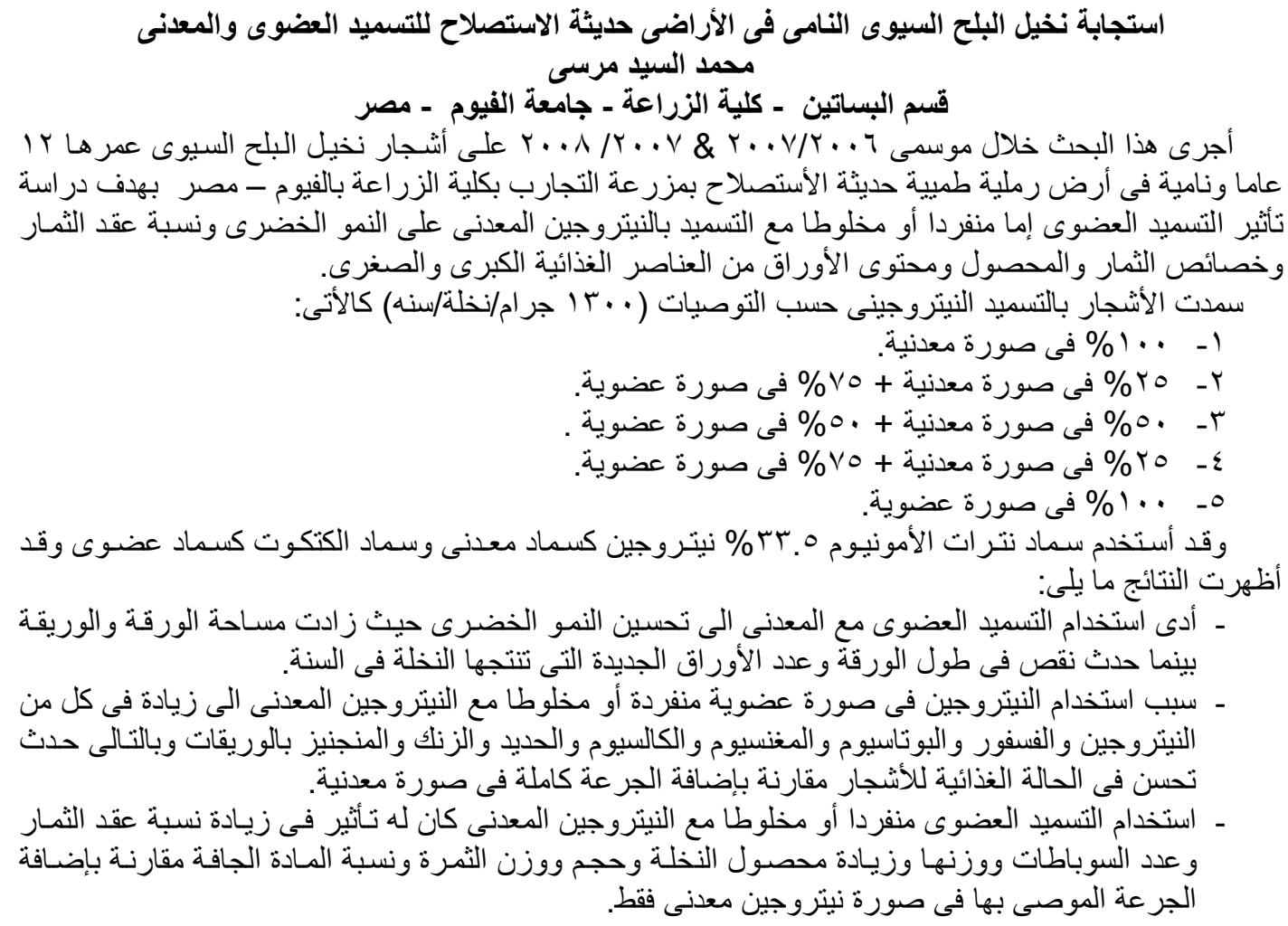

Fayoum J. Agric. Res. \& Dev., Vol.23, No.1, January, 2009 
Morsi, M. E.

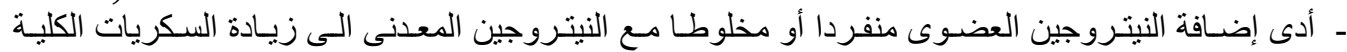

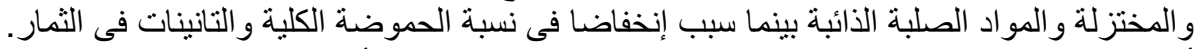

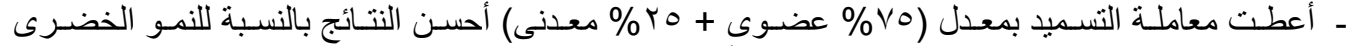
و المحصول وخصائص الثمار و الحالة الغذائية للأشجار .

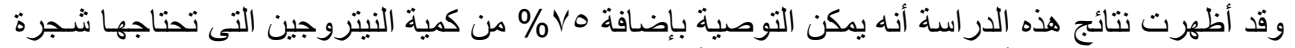

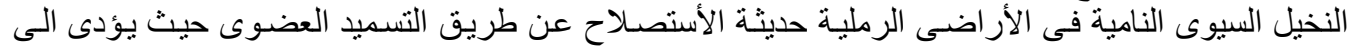

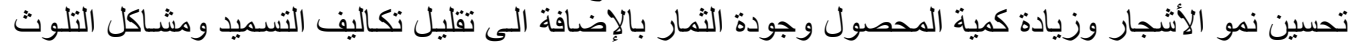
البيئى الناتجة عن استخدام الأسمدة الكيماوية.

Fayoum J. Agric. Res. \& Dev., Vol.23, No.1, January, 2009 